
\title{
25 Research Square \\ Diabetes mellitus indicate poor prognosis in uterine serous cancer patients
}

\section{Yunyun Liu}

Sun Yat-sen Memorial Hospital

Jing Li

Sun Yat-sen Memorial Hospital https://orcid.org/0000-0001-8669-4901

\section{Zhibo Cheng}

Sun Yat-sen Memorial Hospital https://orcid.org/0000-0002-2371-1169

\section{Guocai Xu}

Sun Yat-sen Memorial Hospital

\section{Yongpai Peng ( $\nabla$ pengyoupai@qq.com )}

Sun Yat-sen Memorial Hospital

Lu Huaiwu ( $\nabla$ luhuaiwu@163.com )

Sun Yat-Sen memorial Hospital https://orcid.org/0000-0002-6944-8781

\section{Research Article}

Keywords: uterine serous cancer, Diabetes mellitus, prognosis

Posted Date: June 21st, 2021

DOl: https://doi.org/10.21203/rs.3.rs-261282/v1

License: (c) (1) This work is licensed under a Creative Commons Attribution 4.0 International License. Read Full License 


\section{Abstract}

Purpose. We aimed to find prognostic factors for uterine serous cancer(USC) patients in a retrospective study.

Methods. 51 USC patients between 2010-2020 were enrolled. All pathological specimens were reviewd. The research protocol was approved by Institutional Review Board and all patients were informed consent before the study began. Statistics were done using SPSS 25.0, T test and chi-square analyses were used to compare differences, the overall survival(OS) was estimated with Kaplan-Meier(KM) analysis, univariate and multivariate Cox regression analyses were utilized to find prognostic factors.

Results. The median overall survival(OS) and progressive free survival(PFS) were 75.94 and 63.49 months, respectively. Diagnosed with diabetes mellitus $(P=0.006, \mathrm{HR}=6.792,95 \% \mathrm{Cl}=1.726-26.722)$ and $\mathrm{CA} 125 \llbracket 28 \mathrm{U} / \mathrm{ml}(P=0.006, \mathrm{HR}=7.136,95 \% \mathrm{Cl}=1.780-28.607)$ before surgery were independent risk factors for OS, advanced FIGO stage $(P=0.001, \mathrm{HR}=10.628,95 \% \mathrm{Cl}=2.894-39.026)$ and $\mathrm{DM}(P=0.003, \mathrm{HR}=6.327$, $95 \% \mathrm{Cl}=1.875-21.354)$ were independent factors for PFS. Age $\leq 52$, , tumor size $\geq 2.5 \mathrm{~cm}$ and cervical mucosal infiltration may indicate poor prognosis but were not independent risk factors. Hypertension patients with routine medical treatment tend to survive longer, but there was no statistical differences in OS and PFS compared to patients with normal blood pressure.

Conclusion. In addition to surgical and adjuvant treatments, gynecologists should focus more on the comorbid conditions of USC patiens, especially for DM.

\section{Introduction}

Endometrial cancer(EC) is the $7^{\text {th }}$ most common cancer and the $14^{\text {th }}$ most common cause of cancer death in women, globally[1]. Most EC presented as early-stage disease, with a favorable 5-year overall survival(OS) of greater than $85 \%[1]$. However, uterine serous carcinoma(USC), which is classified into type $2 \mathrm{EC}$, is an aggressive and rare subtupe of EC with an estimated 5 year OS of $18-27 \%$ [2]. USC patients usually suffered from recurrence even in early stage. According to the FIGO guideline, the standard system treatment strategies are surgical staging(for patients with early stage) or debulking surgery(for advanced stage) followed by radiochemotherapy[3]. Improved systemic treatment protocols have prolonged the disease-free survival but have had little effect on long- term overall survival. We aim to find risk factors of disease prognosis in USC patients, which would benefit survivors in providing consulting and management after primary treatment.

Co-morbidities may affect patients' pathological state and prognosis to some extent. Roy showed, cancer survivors had a higher prevalence of hypertension, diabetes mellitus(DM) compared to health people,and among all the cancer type, uterine cancer had the highest prevalence of DM(42.9\%)[4]. Recent evidence suggested, DM may perform a more important biologic link in terms of uterine cancer[5, 6]. Uterine cancer can be classified into type 1 and 2, the former was associated with high estrogen status and insulinresistance, including metabolic syndrome and DM[7]. In 2013, Zanders et al. showed a lower five-year OS 
rate of $68 \%$ compared to $84 \%$ in patients with diabetes and EC[8]. Additional meta-analysis by Liao et al. in 2014 showed a similar pooled relative risk of disease specific mortality of 1.32[6]. USC is type 2 uterine cancer which had a significantly poorer prognosis than type 1 uterine cancer, there were no studies on DM and USC.

\section{Materials And Methods}

A total of 51 patients diagnosed with USC between 2010-2020 were enrolled in this retrospective study, which was approved by hospital institutional review board. Inclusion criteria were as follows: (1) all patiens' pathological specimens were re-reviewd and reconfirmed, (2)received primary operation and firstline adjuvant therapy.

Clinical informations were obtained from medical records. Patients were restage acording to the 2018 FIGO stage. All patients were initial diagnosed and operated in the Memorial Hospital of Sun Yat-sen, Sun Yat-sen University, followed by adjuvant therapy. Information of reccurrence or death were obtained from the follow-up department. In this study, all death was caused by USC, so overall survival was equal to cancer-specific survival(CSS).

Statistics were done using SPSS 25.0(IBM, Armonk, NY, USA). The best cut off value of CA125, tumor size and age were estimated with ROC curve. $T$ test and chi-square analyses were used to compare clinical variables between groups. Significance level is 0.05 . The OS and PFS was calculated using KaplanMeier(KM) analysis and compared using the log-rank test. Univariate and multivariate Cox regression analyses were utilized to find prognostic factors.

The Kaplan-Meier(KM) curves and forest plots were visualized via R 3.6.1, 'survival' and 'survminer' packages were used.

\section{Results}

Of the enrolled 51 patients, 16 had DM. Cut-off values for age, menopause time, CA125, and number of resected lymph nodes were calculated via SPSS using ROC curve.

Most patients(42/51) were dignosed with USC over 52 years old. About $2 / 3$ patients were at early stage. 16 patients didn't receive lymphadenectomy, so we couldn't confirm their pathological status of lymph nodes.

The baselines of patients with or without DM are listed in Table 1. The differences between all the listed factors including stages, BMI, age, and etc were not statistically significant in the 2 group of patients.

The median PFS and OS of all patients were 63.49 months and 75.95 months, respectively(Table 1). The 2-year-OS rate was $85.4 \%$ and 2-year-PFS rate was $77.3 \%$. The OS and PFS rate of patients with DM were significantly lower than those without $\operatorname{DM}(P=0.002$ and 0.029 , respectively, Fig 1 a and Table 1$)$. 
To analyze pathological parameters and co-morbidities in USC patients, univariate and multivariate cox regressions were run. As shown in Table 2, DM was related to a poorer OS. DM and higher stage, BMI, CA125 were unfavourate factors for USC patients' PFS, small tumor size, higher number of resected lymph nodes, and negative lymph nodes were favourate factors for PFS.

In order to find more potential risk factors for OS in multivariate regression analysis, we also include factors with $P$ value $\leq 0.10$ and stage in multivariate analyses. We found that diagnosed with diabetes mellitus $(P=0.006, \mathrm{HR}=6.792,95 \% \mathrm{Cl}=1.726-26.722)$ and $\mathrm{CA} 125 \rrbracket 28 \mathrm{U} / \mathrm{ml}(P=0.006, \mathrm{HR}=7.136,95 \% \mathrm{Cl}=1.780-$ 28.607) before surgery were independent risk factors for OS, the survival curve of these risk factors were shown in Fig 2. Advanced FIGO stage $(P=0.001, \mathrm{HR}=10.628,95 \% \mathrm{Cl}=2.894-39.026)$ and $\mathrm{DM}(P=0.003$, $\mathrm{HR}=6.327,95 \% \mathrm{Cl}=1.875-21.354)$ were independent factors for PFS. Unlike type 1 endometrium cancer, BMI was not related to prognosis of USC.

Interestingly, it indicated that hypertension may be a protect factor for USC patients, which contradicts with mainstream view, but the result was not statistically significant(Fig 1).

\section{Discussion}

USC is a rare but deadly subtype of EC, we conducted a single center retrospective study of 51 patients and found that DM was the independent risk factor of both OS and PFS, the HR were 6.792 and 6.327, respectively.

In our data, about $60 \%$ patients were early stage, which differed from previous study[9]. Almost all patients' complaints were vaginal bleeding or abnormal discharge, which may be the reason for the higher early stage rates of diagnosis.

Only $62.7 \%(32 / 51)$ patients had an accurate pathologic diagnosis before surgery, the rest of patients were mis-diagnosed with endometrioid adenocarcinoma by pre-operation biopsy. According to the famous 'Mayo Criterion', for patients of grade 1-2 stage I EC, with tumor size $₫ 2 \mathrm{~cm}$ and myometrial invasion depth $₫ 1 / 2 \rrbracket$ regional lymphadanectomy could be avoided[10]. But for early stage USC, lymphadanectomy is debatable. In our study, Cox regression showed that although the number of lymph nodes removed was not an independent factor, patients with more lymph nodes resected had a better PFS. As for OS(Figure 2), K-M analysis showed patients without lymph node metastasis had a significantly better prognosis, and the OS of patients whose lymph nodes were not removed was poorer, patients with lymph nodes metastasis had the pooerest end. Li's study enrolled 2853 patients registrated in SEER, the result suggested that patients with $\geq 12$ pelvic lymph nodes (PLNs) removed had significantly better OS than those without (both $\mathrm{P}<0.001$ )[11]. Our results showed the number of lymph nodes removed was not associated with prognosis, we speculated that the small sample size was the reason.

Hence, we think systemic lymph node resection may be recommended to USC patients. Accordingly, the accuracy of pathologic diagnosis before operation was important, cause it directly impacted the decision 
to ressect lymph nodes or not. If we mis-diagnosed an early stage USC as an endometrioid adenocarcinoma, we may make a wrong surgical decision.

DM has reached epidemic preportions worldwidely, its rate shockingly doubled over the last 3 decades[12]. From an gynecologic cancer prospective, the rise in DM impacts patients' medical condition across their lifespan. A direct link between DM and type 1 EC is now well appreciated[13, 14]. Hyperglycemia promoted the development of type 1 endometrial cancer and led to poor prognosis. High blood glucose facilitated EC tumor growth by providing carbon sources for diverse metabolic pathways[13]. In vitro experiments exhibited, the proliferation,adhesion and chemo-resistance of tumor cells were promoted when cultured with high glucose condition[15-17]. There are significant differences in molecular phenotypes and hormone receptor expression between type 1 and type $2 \mathrm{EC}$, thus the prognostic risk factors of the two types may be different. So did DM affect USC patients' survive time? The answer was positive. Our study revealed for the first time that DM was an independent risk factor for OS and PFS in USC patients. Shou did a retrospective analysis in 139 Chinese non-endometrioid adenocarcinoma patients(including 45 USC), he found that metabolic syndrome(MS), stage and age were independent risk factors for OS of USC patients[18]. MS was a group of diseases including DM, hypertension and hyperlipidemia, while our study was focus on DM only.

Surgery and radiochemotherapy are important in USC, but before or after these oncology treatments, we should pay more attention to the control of co-morbidities to improve outcomes. Metformin is commonly used to treat type 2 DM, it may benefit outcomes of EC in an indirect manner[19]. Perez found among postmenopausal women with EC, taking metformin could decrease overall mortality[20]. Sarfstein's study showed that metformin decreased expressions of IGF pathway molecures via inhibition of IGF-IR promotor activities in USC cells, finally promoted cell apoptosis, attanuated cell migration and proliferation[21]. On the contrary, Lilia reported that merformin shortened lifespan of C.elegans and human primary cells when provided in late life[22]. But this research studied individuals with healthy metabolic status. As we know, the peak age of USC is later than type $1 \mathrm{EC}$, therefore, the use of metformin may require more careful selection. Future prospective trials are needed to explore its impact on USC.

Our present study also found that, contrary to previous findings, the prognosis of hypertensive patients seemed to be slightly better than that with normal blood pressure, although the difference was not statistically significant. By increasing the sample size, the differences may be weakened or enlarged.

Limitations of this study are as follows: 1 . Single-center retrospective study with low level of evidence, 2. The sample size is small, but USC is a rare disease, and Gynecologic Cancer InterGroup(GCIG) appeals that it should be separately managed and studied[23], 3. For some patients, the follow-up time is less than 2 years, which may lead to bias.

The advantages of this study is that the operation quality is guaranteed in the famous gynecological tumor center in China. It is the first time that medical comorbidities have been found to influence the prognosis of USC, which will guide the treatment of these patients. 


\section{Abbreviations}

KM:Kaplan Meier, DM: Diabetes mellitus, OS: overall survial time.

\section{Declarations}

Funding: This study was supported by National Science Foundation of China(No.81972433) and Sun Yatsen Clinical Research Program(SYS-C-202001).

Conflicts of interest : All the authors declare no conflicts of interest.

Ethics approval: the study was approved by the institutional review board of Sun Yat-sen Memorial Hospital.

Consent to participate and publication: all the patients enrolled in the study are consent imformed, and we reconfirmed for publication when we did phone call follow-up.

Availibility of data and material: all data and R codes comply with field standard and are availible to all the readers.

\section{Author contribution}

YY Liu: Manuscript writing, Data analysis

J Li: Manuscript editing

ZB Cheng: Data collection

GC Xu: Data analysis

YP Peng: Project development

HW Lu: Project development, Data collection

\section{References}

1. Lortet-Tieulent J, Ferlay J, Bray F, Jemal A (2018) International Patterns and Trends in Endometrial Cancer Incidence, 1978-2013. J Natl Cancer Inst 110(4):354-361

2. del Carmen MG, Birrer M, Schorge JO (2012) Uterine papillary serous cancer: a review of the literature. Gynecol Oncol 127(3):651-661

3. Koh WJ, Abu-Rustum NR, Bean S, Bradley K, Campos SM, Cho KR, Chon HS, Chu C, Cohn D, Crispens MA, Damast S, Dorigo O, Eifel PJ, Fisher CM, Frederick P, Gaffney DK, George S, Han E, Higgins S, Huh WK, Lurain JR 3rd, Mariani A, Mutch D, Nagel C, Nekhlyudov L, Fader AN, Remmenga SW, Reynolds RK, Tillmanns T, Ueda S, Wyse E, Yashar CM, McMillian NR, Scavone JL (2018) Uterine Neoplasms, 
Version 1.2018, NCCN Clinical Practice Guidelines in Oncology. J Natl Compr Canc Netw 16(2):170199

4. Roy S, Vallepu S, Barrios C, Hunter K (2018) Comparison of Comorbid Conditions Between Cancer Survivors and Age-Matched Patients Without Cancer. J Clin Med Res 10(12):911-919

5. Lees B, Leath CA 3 (2015) The Impact of Diabetes on Gynecologic Cancer: Current Status and Future Directions. Curr Obstet Gynecol Rep 4(4):234-239 rd, ) )

6. Luo J, Beresford S, Chen C, Chlebowski R, Garcia L, Kuller L, Regier M, Wactawski-Wende J, Margolis $\mathrm{KL}$ (2014) Association between diabetes, diabetes treatment and risk of developing endometrial cancer. Br J Cancer 111(7):1432-1439

7. Bokhman JV (1983) Two pathogenetic types of endometrial carcinoma. Gynecol Oncol 15(1):10-17

8. Zanders MM, Boll D, van Steenbergen LN, van de Poll-Franse LV, Haak HR (2013) Effect of diabetes on endometrial cancer recurrence and survival. Maturitas 74(1):37-43

9. Naumann RW (2008) Uterine papillary serous carcinoma: state of the state. Curr Oncol Rep 10(6):505-511

10. Colombo N, Creutzberg C, Amant F, Bosse T, Gonzalez-Martin A, Ledermann J, Marth C, Nout R, Querleu D, Mirza MR, Sessa C, E.-E.-E.E.C.C.W. Group, ESMO-ESGO-ESTRO Consensus Conference on Endometrial Cancer: Diagnosis, Treatment and Follow-up, Int J Gynecol Cancer 26(1) (2016) 2-30

11. Li H, Xie X, Liu Y, Huang X, Lin H, Li J, Lin Z (2020) Comprehensive lymphadenectomy and survival prediction in uterine serous cancer patients after surgery: A population-based analysis. Eur $\mathrm{J}$ Surg Oncol 46(7):1339-1346

12. Zimmet PZ, Magliano DJ, Herman WH, Shaw JE (2014) Diabetes: a 21st century challenge. Lancet Diabetes Endocrinol 2(1):56-64

13. Byrne FL, Martin AR, Kosasih M, Caruana BT, Farrell R, The Role of Hyperglycemia in Endometrial Cancer Pathogenesis, Cancers (Basel) 12(5) (2020)

14. Lucenteforte E, Bosetti C, Talamini R, Montella M, Zucchetto A, Pelucchi C, Franceschi S, Negri E, Levi F (2007) C. La Vecchia, Diabetes and endometrial cancer: effect modification by body weight, physical activity and hypertension. Br J Cancer 97(7):995-998

15. Garufi A, Traversi G, Gilardini Montani MS, D'Orazi V, Pistritto G, Cirone M (2019) G. D'Orazi, Reduced chemotherapeutic sensitivity in high glucose condition: implication of antioxidant response. Oncotarget 10(45):4691-4702

16. Han J, Zhang L, Guo H, Wysham WZ, Roque DR, Willson AK, Sheng X, Zhou C, Bae-Jump VL (2015) Glucose promotes cell proliferation, glucose uptake and invasion in endometrial cancer cells via AMPK/mTOR/S6 and MAPK signaling. Gynecol Oncol 138(3):668-675

17. Gu CJ, Xie F, Zhang B, Yang HL, Cheng J, He YY, Zhu XY, Li DJ, Li MQ (2018) High Glucose Promotes Epithelial-Mesenchymal Transition of Uterus Endometrial Cancer Cells by Increasing ER/GLUT4Mediated VEGF Secretion. Cell Physiol Biochem 50(2):706-720 
18. Shou H, Yan K, Song J, Zhao L, Zhang Y, Ni J (2020) Metabolic syndrome affects the long-term survival of patients with non-endometrioid carcinoma of the uterine corpus. Int $\mathrm{J}$ Gynaecol Obstet 148(1):96-101

19. Meireles CG, Pereira SA, Valadares LP, Rego DF, Simeoni LA, Guerra ENS, Lofrano-Porto A (2017) Effects of metformin on endometrial cancer: Systematic review and meta-analysis. Gynecol Oncol 147(1):167-180

20. Perez-Lopez FR, Pasupuleti V, Gianuzzi X, Palma-Ardiles G, Hernandez-Fernandez W, Hernandez AV (2017) Systematic review and meta-analysis of the effect of metformin treatment on overall mortality rates in women with endometrial cancer and type 2 diabetes mellitus. Maturitas 101:6-11

21. Sarfstein R, Friedman Y, Attias-Geva Z, Fishman A, Bruchim I, Werner H (2013) Metformin downregulates the insulin/IGF-I signaling pathway and inhibits different uterine serous carcinoma (USC) cells proliferation and migration in p53-dependent or -independent manners. PLoS One 8(4):e61537

22. Espada L, Dakhovnik A, Chaudhari P, Martirosyan A, Miek L, Poliezhaieva T, Schaub Y, Nair A, Doring N, Rahnis N, Werz O, Koeberle A, Kirkpatrick J, Ori A, Ermolaeva MA, Loss of metabolic plasticity underlies metformin toxicity in aged Caenorhabditis elegans, Nat Metab (2020)

23. Sagae S, Susumu N, Viswanathan AN, Aoki D, Backes FJ, Provencher DM, Vaughan M, Creutzberg CL, Kurzeder C, Kristensen G, Lee C, Kurtz JE, Glasspool RM, Small W (2014) Jr., Gynecologic Cancer InterGroup (GCIG) consensus review for uterine serous carcinoma. Int J Gynecol Cancer 24(9 Suppl 3):S83-S89

\section{Tables}

Table 1. Baseline features of uterine serous carcinoma patients with or without DM. 


\begin{tabular}{|c|c|c|c|c|}
\hline Characteristics & $\frac{\text { Total }}{\mathrm{n}=51}$ & $\begin{array}{c}\text { Without DM } \\
\mathrm{n}=35\end{array}$ & $\begin{array}{c}\mathrm{DM} \\
\mathrm{n}=16\end{array}$ & Pvalue \\
\hline $\begin{array}{l}\text { Age } \\
052\end{array}$ & $9 \square 17.6 \% \square$ & 6ロ17.1\%ロ & 3ロ18.8\%ロ & 0.588 \\
\hline$\geq 52$ & $42 \square 82.4 \% \square$ & $29 \square 82.9 \% \square$ & $13 \square 81.3 \% \square$ & \\
\hline Menopause time (year) & & & & 0.519 \\
\hline $\begin{array}{l}76.5 \\
>65\end{array}$ & $21 \square 41.2 \% \square$ & $14 \square 40.0 \% \square$ & $\begin{array}{l}\text { 7ロ43.8\%ם } \\
9 \square 56.3 \% \square\end{array}$ & \\
\hline $\begin{array}{l}\geq 6.5 \\
\text { Tumor size }(\mathrm{cm})\end{array}$ & & $21 \square 60.0 \% \square$ & & 0.159 \\
\hline $\begin{array}{l}\leq 2.5 \\
\square 2.5\end{array}$ & $\begin{array}{l}26 \square 51 \% \square \\
25 \square 49 \% \square\end{array}$ & $\begin{array}{l}20 \square 57.1 \% \square \\
15 \square 42.9 \% \square\end{array}$ & $\begin{array}{l}6 \square 37.5 \% \square \\
10 \square 62.5 \% \square\end{array}$ & \\
\hline FIGO stage & & & & 0.140 \\
\hline Early $\mathrm{II}-\mathrm{II} \square$ & $31 \square 60.7 \% \square$ & $20 \square 57.1 \% \square$ & $11 \square 68.8 \% \square$ & \\
\hline Late $\llbracket I I I-I V \square$ & $20 \square 39.2 \% \square$ & 15ロ42.9\%ם & $5 \square 31.2 \% \square$ & \\
\hline BMI & & & & 0.481 \\
\hline$\leq 24$ & 30ロ58.8\%ם & $20 \square 57.1 \% \square$ & $10 \square 62.5 \% \square$ & \\
\hline$\square 24$ & $21 \square 41.2 \% \square$ & $15 \square 42.9 \% \square$ & 6ロ37.5\%ロ & \\
\hline CA125(U/mL) & & & & 0.548 \\
\hline $\begin{array}{l}\leq 28 \\
\square 28\end{array}$ & 34ロ66.7\%ם & 23ロ65.7\%ם & 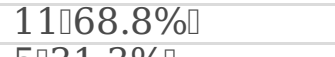 & \\
\hline LVSI & & 1 СШU4.ப & & 0.159 \\
\hline Positive & $21 \square 41.2 \% \square$ & $15 \square 42.9 \% \square$ & $10 \square 62.5 \% \square$ & \\
\hline Negative & 30ロ56.9\%ם & $20 \square 57.1 \% \square$ & 6ロ37.5\%ロ & \\
\hline LN status & & & & 0.787 \\
\hline Unknown & $16 \square 31.4 \% \square$ & $11 \square 31.4 \% \square$ & $5 \square 31.3 \% \square$ & \\
\hline Negative & $25 \square 49.0 \% \square$ & $18 \square 51.4 \% \square$ & 7ロ43.8\%ם & \\
\hline Positive & 10ロ19.6\%ロ & 6ロ17.1\%ロ & 4ロ25.0\%ם & \\
\hline Cervical mucosal invasion & & & & 0.224 \\
\hline Negative & 31ธ60.8\%ם & 23ロ65.7\%ם & $8 \square 50 \% \square$ & \\
\hline Positive & 20ロ39.2\%ם & $12 \square 34.3 \% \square$ & $8 \square 50 \% \square$ & \\
\hline Myometrial invasion & & & & 0.224 \\
\hline$\square 1 / 2$ & 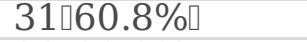 & $23 \square 65.7 \% \square$ & 8๑50\%ロ & \\
\hline$\geq 1 / 2$ & $20 \square 39.2 \% \square$ & $12 \square 34.3 \% \square$ & $8 \square 50 \% \square$ & \\
\hline Num of LN & & & & 0.305 \\
\hline None & $16 \square 31.4 \% \square$ & $12 \square 34.3 \% \square$ & $4 \square 25.0 \% \square$ & \\
\hline 020 & $11 \square 21.6 \% \square$ & $9 \square 25.7 \% \square$ & $2 \square 12.5 \% \square$ & \\
\hline$\geq 20$ & $24 \square 47.1 \% \square$ & $14 \square 40.0 \% \square$ & $10 \square 62.5 \% \square$ & \\
\hline Median PFS & $63.49 \% \pm 7.32 \%$ & $73.75 \% \pm 8.78 \%$ & $47.08 \% \pm 12.57 \%$ & $0.016^{*}$ \\
\hline Median OS & $75.94 \% \pm 7.75 \%$ & $94.59 \% \pm 7.68 \%$ & $47.67 \% \pm 10.91 \%$ & $0.030^{*}$ \\
\hline 2-years-PFS & $77.3 \% \pm 6.8 \%$ & $88.4 \% \pm 6.4 \%$ & $41 \% \pm 15.9 \%$ & $0.029^{*}$ \\
\hline 2-years-OS & $85.4 \% \pm 6.1 \%$ & $90.2 \% \pm 6.6 \%$ & $67.1 \% \pm 13.8 \%$ & $0.002^{*}$ \\
\hline
\end{tabular}

Legends: chi-square analysis was used to compare differences. Of all the features listed, there were no statistical differences between patients with or without DM. Thus baseline characteristics were well balanced between the two arms. Logrank analysis showed that the PFS and OS were significantly poorer in DM arm. *:P®0.05.

\section{Abbreviations:}

DM: Diabetes Mellitus, FIGO: International Federation of Gynecology and Obstetrics, BMI: body mass index, LVSI: lymph-vascular space invasion, LN status: lymph node metastasis status, Num of LN: numbers of resected lymph nodes, OS: overall survial time, PFS:progressive free survival time. 
Table 2. Univariate cox regression for OS and PFS

\begin{tabular}{|c|c|c|c|c|c|c|}
\hline & \multicolumn{3}{|c|}{ PFS } & \multicolumn{3}{|c|}{$O S$} \\
\hline & HR & $95 \%$ CI & $P$ & $\mathrm{HR}$ & 95\%CI & $P$ \\
\hline & 0.13 & $0.00-5.15$ & 0.28 & 0.30 & $0.00-31.06$ & 0.61 \\
\hline ause time & 2372 & $\begin{array}{l}1.45-48.53 \\
0.24-237584\end{array}$ & 0.02 & $\begin{array}{l}9.05 \\
1.88\end{array}$ & $\begin{array}{l}0.02-14 / .01 \\
0.00-120007\end{array}$ & 0.11 \\
\hline & & $0.85-21.14$ & 0.08 & 2.30 & $0.13-39.20$ & 0.57 \\
\hline al mucosal invasion & 1.00 & 0.1 & 1.00 & 0.19 & $0.01-6.20$ & 0.35 \\
\hline size & 0.0 & & 0.01 & 0.96 & $0.04-23.47$ & 0.98 \\
\hline us & 0.15 & -0.73 & 0.02 & 0.59 & $0.06-5.71$ & 0.65 \\
\hline $\mathrm{LN}$ & & & 0.04 & 1.28 & 0.1 & 0.81 \\
\hline & 212.54 & 4.01 & 0.001 & 8.4 & 237.73 & 0.21 \\
\hline$(\mathrm{U} / \mathrm{ml})$ & 12.43 & & 0.02 & 11.13 & $0.72-171.02$ & 0.08 \\
\hline & 94.83 & 32.20 & 0.001 & 34.09 & $1.70-684.91$ & 0.02 \\
\hline
\end{tabular}

Legends: Univariate cox regressions showed that DM and advanced stage, higher BMI, CA125 were unfavourate factors for USC patients' PFS, small tumor size, higher number of resected lymph nodes, and negative lymph nodes were favourate factors for PFS. DM was the only risk factor for OS.

\section{Abbreviations:}

DM: Diabetes Mellitus, BMI: body mass index, LN status: lymph node metastasis status, Num of LN: numbers of resected lymph nodes, OS: overall survial time, PFS:progressive free survival time, HR: hazard rate, CI: confidence interval.

\section{Figures}
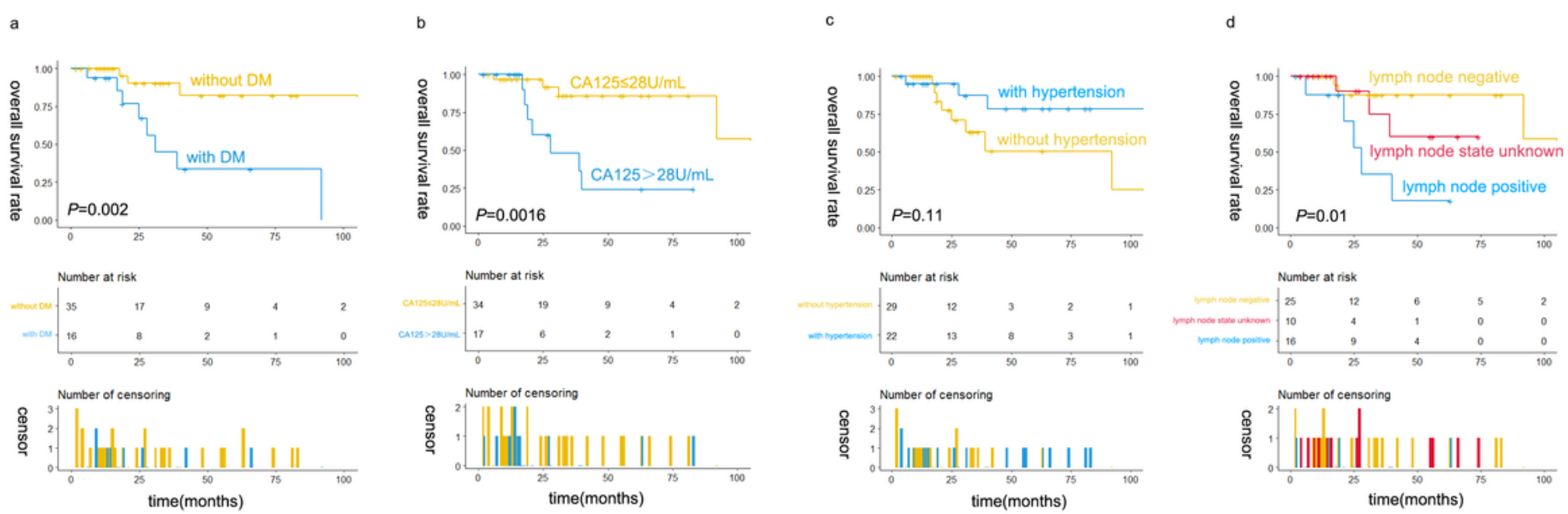

Figure 1 
Kaplan-Meier survival curves of USC patients a) The KM curve for patients with(blue curve) of without DM(yellow curve) ( $P=0.002)$. b) The KM curve for USC patients with CA125 $\leq 28 \mathrm{U} / \mathrm{L}$ (yellow curve) and CA125 $28 \mathrm{U} / \mathrm{L}$ (blue curve) $(\mathrm{P}=0.0016)$. C) The KM curve for USC patients with hypertension(blue curve) was higher compared with patients without hypertension(yellow curve), but the difference did not reach statistical significance $(P=0.11)$. $d)$ The KM curve of lymph node status for USC patients $(P=0.01)$, the prognosis of patients without lymph nodes metastasis were better than the group of patients whose lymph nodes were not resected, patients with lymph nodes invasion suffered the worst prognosis 